\title{
A Janus-Like Role of CREB Protein: Enhancement of Synaptic Property in Mature Neurons and Suppression of Synaptogenesis and Reduced Network Synchrony in Early Development
}

\author{
Mio Nonaka \\ Department of Neurochemistry, Graduate School of Medicine, University of Tokyo, Bunkyo-ku, Tokyo 113-0033, Japan \\ Review of Aguado et al. (http://www.jneurosci.org/cgi/content/full/29/2/328)
}

The cAMP response element (CRE)binding protein (CREB) is a transcription factor that binds to CRE sequences (consensus, TGACGTCA) that are present within the promoters of many neuronal genes and is activated in response to various signaling cascades. CREB, cAMPresponsive element modulator (CREM), and activating transcription factor-1 (ATF-1) constitute the CREB/ATF family of bZIP transcription factors and regulate many physiologically critical functions such as cell proliferation, survival, differentiation, cell morphology, and synaptic plasticity (Shaywitz and Greenberg, 1999).

CREB has several splice variants, among which $\alpha$-, $\beta$-, and $\Delta$-isoforms function in the brain. The first Creb knock-out $(C r e b 1 \alpha \Delta)$ (Bourtchuladze et al., 1994; Hummler et al., 1994) showed no gross abnormalities of development, likely because CREM and CREB $\beta$ were upregulated to compensate for the loss of

Received March 18, 2009; revised April 9, 2009; accepted April 13, 2009.

M.N. is supported by a postdoctoral fellowship from the Japan Society for the Promotion of Science. I thank Dr. Haruhiko Bito for invaluable comments and encouragements.

Correspondence should be addressed to Mio Nonaka, Department of Neurochemistry, Graduate School of Medicine, University of Tokyo, 7-3-1 Hongo, Bunkyo-ku, Tokyo 113-0033, Japan. E-mail: nonaka@m.u-tokyo. ac.jp.

DOI:10.1523/JNEUROSCI.1309-09.2009

Copyright $\odot 2009$ Society for Neuroscience $\quad$ 0270-6474/09/296389-03\$15.00/0
CREB function (see Table 1 for a summary of Creb and/or Crem knock-outs). To create a full Creb knock-out, Rudolph et al. (1998) disrupted exons that code the essential bZIP domain of CREB. This mouse, Creb1 ${ }^{-1-}$ had gross growth defects and died perinatally. At embryonic day 18.5 (E18.5), Creb1 ${ }^{-1-}$ mice had smaller corpus callosum and anterior commissures, indicating an axonal phenotype. However, again, CREM was upregulated in these knock-outs, thus complicating the interpretation (Rudolph et al., 1998).

For these reasons, it was necessary to create a Creb/Crem double knock-out mouse. Furthermore, because CREB plays essential roles in many organs, and to distinguish the contribution of CREB in adult plasticity from CREB's function during development, temporally and spatially controlled conditional knock-outs were much awaited. Mantamadiotis et al. (2002) took advantage of the specific promoter driven Cre mouse technology and the Cre/loxP system to produce several cell lineage-restricted and temporally controlled Creb knock-out mice. In one of those mouse lines, Creb ${ }^{\text {Nescre }}$, Creb deletion was restricted to neuronal and glial progenitor cells at E16.5 and onward. This mouse was then crossed with a Crem knock-out line to obtain a conditional $\mathrm{Creb}$, global Crem double-mutant mouse
$\left(\mathrm{Creb}^{\mathrm{Nescre}} \mathrm{Crem}^{-1-}\right)$. Disruption of both Creb and Crem should eliminate CREB/ ATF family functions in the nervous system, since ATF-1 is not normally expressed in brain and was not upregulated in the Creb knock-outs. Creb ${ }^{\text {Nescre }} \mathrm{Crem}^{-1-}$ mice died perinatally, because of milk suckling inability. Perinatal immunohistochemical analysis revealed that the double mutant displayed drastic loss of neurons throughout the brain with enlarged ventricles, attributable to increased neuronal apoptosis rather than reduced progenitor proliferation.

Mantamadiotis et al. (2002) also produced $\mathrm{Creb} / \mathrm{Crem}$ knock-out mice with a late onset of CREB loss $\left(\mathrm{Creb}^{\mathrm{Camkcre} 4} \mathrm{Crem}^{-/-}\right)$to investigate the function of CREB/CREM in adult neurons. This mouse exhibited progressive neuronal loss in hippocampus CA1, dentate gyrus, and dorsolateral striatum.

This severe neurodegeneration phenotype is consistent with a role of CREB in growth factor-dependent survival originally identified in sympathetic neurons by Riccio et al. (1999). However, whereas the growth factor-dependent survival involves expression of $\mathrm{Bcl} 2$, an antiapoptotic gene, the gross neurodegeneration phenotype seen in $\mathrm{Creb}^{\mathrm{Nescre}} \mathrm{Crem}^{-1-}$ mice and region-specific neurodegeneration in $\mathrm{Creb}^{\text {Camkcre }^{4}} \mathrm{Crem}^{-1-}$ mice did not appear to be caused by misregulation of 
Table 1. A brief summary of Creb and/or Crem knock-out mice

\begin{tabular}{|c|c|c|c|c|c|}
\hline Knock-out & $\begin{array}{l}\text { CREB/ATF family } \\
\text { expressed in brain }\end{array}$ & Conditional expression & Viability & $\begin{array}{l}\text { Major phenotypes in the nervous } \\
\text { system }\end{array}$ & References \\
\hline $\mathrm{Creb}^{\alpha \Delta}$ & CREB $\beta$, CREM & & Viable to adulthood & $\begin{array}{l}\text { No gross abnormality of development; } \\
\text { deficient long-term memory }\end{array}$ & $\begin{array}{l}\text { Hummler et al., } 1994 \\
\text { Bourtchuladze et al., } 1994 \\
\text { Blendy et al., 1996b }\end{array}$ \\
\hline $\mathrm{Creb1}^{-1-}$ & CREM & & Perinatal death & $\begin{array}{l}\text { Enlarged ventricles; reduced } \\
\text { commissures }\end{array}$ & Rudolph et al., 1998 \\
\hline $\mathrm{Crem}^{-1-}$ & CREB & & Viable to adulthood & $\begin{array}{l}\text { Circadian rhythm abnormalities; lower } \\
\text { anxiety levels }\end{array}$ & $\begin{array}{l}\text { Nantel et al., } 1996 \\
\text { Blendy et al., 1996a } \\
\text { Maldonado et al., } 1999\end{array}$ \\
\hline $\mathrm{Creb}^{\text {Nescre }} \mathrm{Crem}^{-1-}$ & & $\begin{array}{l}\text { Developmental (E16.5 and } \\
\text { onward) in neuronal and } \\
\text { glial progenitors }\end{array}$ & Perinatal death & $\begin{array}{l}\text { Progressive neurodegeneration in all } \\
\text { areas of the brain }\end{array}$ & $\begin{array}{c}\text { Mantamadiotis et al., } 2002 \\
\text { Aguado et al., } 2009\end{array}$ \\
\hline $\mathrm{Creb}^{\text {Camkcre4}} \mathrm{Crem}^{-/-}$ & & $\begin{array}{l}\text { Postnatal in forebrain } \\
\text { regions }\end{array}$ & Viable to adulthood & $\begin{array}{l}\text { Progressive neurodegeneration in } \\
\text { hippocampus and striatum }\end{array}$ & Mantamadiotis et al., 2002 \\
\hline
\end{tabular}

the antiapoptotic and proapoptotic $\mathrm{Bcl} 2$ family (Mantamadiotis et al., 2002). It is noteworthy that such neurodegeneration was only present in the Creb/Crem double knock-outs and not identified in either Creb or Crem single knock-outs, an issue discussed later in this article.

Aguado et al. (2009) used the $\mathrm{Creb}^{\text {Nescre }} \mathrm{Crem}^{-1-}$ mice described above and focused on prenatal synaptogenesis, a process that had not been extensively explored. The authors expected that synapse density would be decreased, because CREB activity was previously shown to increase spine density (Murphy and Segal, 1997). A careful electron microscopic study was performed, and synaptic contacts were quantified in E18 embryos of control, Creb/Crem single knock-outs, and $\mathrm{Creb}^{\text {Nescre }} \mathrm{Crem}^{-1-}$ mice, in two layers of the hippocampus where pyramidal neuron receive dense inputs. Contrary to expectations, however, synaptic density increased rather than decreased in the hippocampus of double-mutant compared with wild-type mice [Aguado et al. (2009), their Fig. 1]. Creb and Crem single mutants also displayed a significant but smaller increase. No changes in the overall structure of synapses were discernible by electron microscopy.

A second intriguing phenotype was revealed when spontaneous activity of hippocampal neurons was examined in slices using a calcium dye, fura- 2 . In mutant slices, the fraction of active cells was significantly larger, and the frequency and synchrony of spontaneous activity was higher [Aguado et al. (2009), their Fig. 2], in accordance with the increased synaptic contacts. From these data, the authors concluded that CREB is a negative regulator for synaptogenesis and spontaneous network activity during prenatal development.
This new work sheds light on the critical involvement of CREB in the refinement of synaptic connectivity during early brain development. Importantly, it revealed a strong correlation between outnumbered synapses and strengthened synchrony. However, at the stage examined, $\mathrm{Creb}^{\mathrm{Nescre}} \mathrm{Crem}^{-1-}$ mice already suffered increased apoptosis in the hippocampus, which started as early as E16.5 (Mantamadiotis et al., 2002). Therefore, although the information on neuronal density was not provided, it is possible that the increased synaptogenesis was a secondary homeostatic effect to compensate for neuronal loss, which also may have triggered enhanced network activity. To address these issues, future work should investigate whether enhanced CREB activity during development suppresses synaptogenesis and network correlation, and a temporally restricted rescue experiment should be attempted on the double knock-out background.

What is the source for the nonevoked calcium rise measured by Aguado et al. (2009)? Synchronous activity in developing neurons is believed to help build neural networks, although its origin is not fully understood. With pharmacological assays, the authors showed that the spontaneous activity depended mainly on extracellular $\mathrm{Ca}^{2+}$ and that $\mathrm{GABA}_{\mathrm{A}}$ receptor and glutamate receptors were partially ( $\sim 60 \%)$ involved [Aguado et al. (2009), their Fig. 3]. Interestingly, both $\mathrm{GABA}_{\mathrm{A}}$ receptor and glutamate receptor antagonists abrogated network activity correlation, indicating that excitatory GABA input and glutamate input are both important for circuit refinement. The increased activity in $\mathrm{Creb}^{\mathrm{Nescre}} \mathrm{Crem}^{-1-}$ hippocampus also essentially depended on extracellular $\mathrm{Ca}^{2+}$ and involved $\mathrm{GABA}_{\mathrm{A}}$ and glutamate receptors, the expression levels of which were not altered. Thus, it is likely that increased innervation is the main cause for the enhanced activity. However, it still remains to be determined whether the lack of CREB/CREM raised the activity and synchrony of immature neurons via solely trans-synaptic mechanisms or multiple mechanisms involving intracellular $\mathrm{Ca}^{2+}$ mobilization or other $\mathrm{Ca}^{2+}$ sources such as gap junctions.

Aguado et al. (2009) have presented situations in which CREB/ATF family members do not fully compensate for each other's loss: although Creb or Crem single mutants did not display increased apoptosis or progressive neuronal death as in the double mutant, single Creb or Crem mutants have intermediate phenotypes for enhanced prenatal synaptogenesis and spontaneous network activity. This implies that CREB and CREM can fully compensate for survival and neurodegeneration, but their functions on synaptogenesis and spontaneous network activity may not be completely redundant or could have dosage dependency.

The enhanced synaptogenesis and spontaneous activity in $\mathrm{Creb}^{\mathrm{Nescre}} \mathrm{Crem}^{-1-}$ mice revealed by Aguado et al. (2009) is surprising given that CREB is widely thought to mediate calcium- and cAMP-dependent gene expression to strengthen neuronal network in long-term potentiation, learning, and memory. Several studies have shown a correlation between increased CREB activity and enhanced synaptogenesis in mature neurons (Murphy and Segal, 1997). The unexpected negative regulation by CREB demonstrated here could in part be explained by a difference in developmental stages. E18 is when weak spontaneous activities prune synaptic connections before receiving external inputs. During the first or second weeks after birth, as the mice receive sensory inputs, hippocampal pyramidal neurons 
undergo drastic changes. GABA switches from excitation to inhibition, axons and dendrites elaborate to form numerous synapses, and receptors and channels alter their properties by exchanging subunits and/or being escorted by scaffolds (Tyzio et al., 1999; Sans et al., 2000). Given such drastic transitions, it is not inconceivable, yet still remarkable, that the polarity of CREB action is subject to a complete conversion, from negative to positive. Another possible interpretation is that CREB is involved in the sculpting phase, after the initial massive synaptogenesis during development. The authors did not determine whether the increased synaptic terminals were active/ silent, glutamatergic/GABAergic, or symmetric/asymmetric. Marie et al. (2005) previously addressed this issue in mature hippocampal neurons, by forced expression of constitutively active CREB, and showed that this manipulation resulted in increased spine density but with the net increase being restricted to NMDA receptor-only silent synapses.

What is the mechanism underlying the opposite effects of CREB in different contexts? Numerous CREB target genes have been proposed, and it is very likely that different subsets of these target genes are upregulated under each context. The outstanding question is how this can be achieved downstream of a single factor. First, active CREB is believed to form a large protein complex and is accompanied by many other cofactors including a recently identified coactivator (Li et al., 2009); the combination of coactivators may help CREB differentially activate CRE-containing promoters. Second, CREB not only forms homodimers but can heterodimerize with CREM and ATF-1. The significance and activities of these heteromers are not well known, but they might significantly contribute to increase the repertoire of CREB function. Third, it has recently been revealed that the promoters of immediate early genes often contain more than two cis- regulatory elements in close proximity to each other, which potentially enables higher-order regulation by crosstalk with other transcriptional factors responding to the same stimuli (Kawashima et al., 2009). Finally, many CREB kinases have been identified. The activation profile of these upstream kinases may differentially govern the ultimate outcomes. Future detailed studies on the individual CREB target promoters, CREB coactivators, and downstream gene expression profiles should clarify the mechanisms for the dual-function of CREB in neurons and provide in-depth insights on the complexity and the functional richness of physiological events regulated by CREB and related transcription factors.

\section{References}

Aguado F, Díaz-Ruiz C, Parlato R, Martínez A, Carmona MA, Bleckmann S, Ureña JM, Burgaya F, del Río JA, Schütz G, Soriano E (2009) The CREB/CREM transcription factors negatively regulate early synaptogenesis and spontaneous network activity. J Neurosci 29:328-333.

Blendy JA, Kaestner KH, Weinbauer GF, Nieschlag E, Schütz G (1996a) Severe impairment of spermatogenesis in mice lacking the CREM gene. Nature 380:162-165.

Blendy JA, Kaestner KH, Schmid W, Gass P, Schutz G (1996b) Targeting of the CREB gene leads to up-regulation of a novel CREB mRNA isoform. EMBO J 15:1098-1106.

Bourtchuladze R, Frenguelli B, Blendy J, Cioffi D, Schutz G, Silva AJ (1994) Deficient longterm memory in mice with a targeted mutation of the cAMP-responsive element-binding protein. Cell 79:59-68.

Hummler E, Cole TJ, Blendy JA, Ganss R, Aguzzi A, Schmid W, Beermann F, Schütz G (1994) Targeted mutation of the CREB gene: compensation within the CREB/ATF family of transcription factors. Proc Natl Acad Sci U S A 91:5647-5651.

Kawashima T, Okuno H, Nonaka M, AdachiMorishima A, Kyo N, Okamura M, Takemoto-Kimura S, Worley PF, Bito $\mathrm{H}$ (2009) Synaptic activity-responsive element in the Arc/Arg3.1 promoter essential for synapse-to-nucleus signaling in activated neurons. Proc Natl Acad Sci U S A 106:316-321.

Li S, Zhang C, Takemori H, Zhou Y, Xiong ZQ
(2009) TORC1 regulates activity-dependent CREB-target gene transcription and dendritic growth of developing cortical neurons. J Neurosci 29:2334-2343.

Maldonado R, Smadja C, Mazzucchelli C, Sassone-Corsi P, Mazucchelli C (1999) Altered emotional and locomotor responses in mice deficient in the transcription factor CREM. Proc Natl Acad Sci U S A 96:14094-14099.

Mantamadiotis T, Lemberger T, Bleckmann SC, Kern H, Kretz O, Martin Villalba A, Tronche F, Kellendonk C, Gau D, Kapfhammer J, Otto C, Schmid W, Schütz G (2002) Disruption of CREB function in brain leads to neurodegeneration. Nat Genet 31:47-54.

Marie H, Morishita W, Yu X, Calakos N, Malenka RC (2005) Generation of silent synapses by acute in vivo expression of CaMKIV and CREB. Neuron 45:741-752.

Murphy DD, Segal M (1997) Morphological plasticity of dendritic spines in central neurons is mediated by activation of cAMP response element binding protein. Proc Natl Acad Sci U S A 94:1482-1487.

Nantel F, Monaco L, Foulkes NS, Masquilier D, LeMeur M, Henriksén K, Dierich A, Parvinen M, Sassone-Corsi P (1996) Spermiogenesis deficiency and germ-cell apoptosis in CREMmutant mice. Nature 380:159-162.

Riccio A, Ahn S, Davenport CM, Blendy JA, Ginty DD (1999) Mediation by a CREB family transcription factor of NGF-dependent survival of sympathetic neurons. Science 286:2358-2361.

Rudolph D, Tafuri A, Gass P, Hämmerling GJ, Arnold B, Schütz G (1998) Impaired fetal T cell development and perinatal lethality in mice lacking the cAMP response element binding protein. Proc Natl Acad Sci U S A 95:4481-4486.

Sans N, Petralia RS, Wang YX, Blahos J 2nd, Hell JW, Wenthold RJ (2000) A developmental change in NMDA receptor-associated proteins at hippocampal synapses. J Neurosci 20:1260-1271.

Shaywitz AJ, Greenberg ME (1999) CREB: a stimulus-induced transcription factor activated by a diverse array of extracellular signals. Annu Rev Biochem 68:821-861.

Tyzio R, Represa A, Jorquera I, Ben-Ari Y, Gozlan H, Aniksztejn L (1999) The establishment of GABAergic and glutamatergic synapses on CA1 pyramidal neurons is sequential and correlates with the development of the apical dendrite. J Neurosci 19:10372-10382. 